\title{
Iron supplementation for lambs experimentally infected by Haemonchus contortus: response to anemia and iron store in the bone marrow ${ }^{1}$
}

\begin{abstract}
Valeska P. Casanova ${ }^{2}$, Adelina R. Aires², Silvana G. Collet ${ }^{2}$, Alexandre Krause ${ }^{3}$, Rafael N. Moresco ${ }^{4}$, Guilherme V. Bochi ${ }^{4}$, Aleksandro S. Silva ${ }^{5}$ and Marta L.R. Leal ${ }^{2 *}$

ABSTRACT.- Casanova V.P., Aires A.R., Collet S.G., Krause A., Moresco R.N., Bochi G.V., Silva A.S. \& Leal M.L.R. 2018. Iron supplementation for lambs experimentally infected by Haemonchus contortus: response to anemia and iron store in the bone marrow. Pesquisa Veterinária Brasileira 38(8):1543-1548. Departamento de Grandes Animais, Universidade de Santa Maria, Avenida Roraima 1000, Santa Maria, RS 97105-900, Brazil. E-mail: martalizandra@gmail.com

To evaluate the effect of supplementation of iron dextran on blood variables and iron metabolism in lambs experimentally infected by Haemonchus contortus, four experimental groups were used: uninfected and non-supplemented animals (GI); infected animals supplemented with iron (GII); uninfected animals supplemented with iron (GIII); and infected non-supplemented animals (GIV). Groups II and IV received 10,000 larvae (L3) of Haemonchus contortus, and groups II and III received three doses of iron dextran $(20 \mathrm{mg} / \mathrm{kg})$ intramuscularly with seven days of interval. Blood and faeces samples were collected on days 10 (D10), 17 (D17), 24 (D24), and 31 (D31), in order to determine red blood cell counts, iron metabolism, and EPG. Infected animals developed anemia from D24 and anemia was more severe on D31. Animals from GII had higher hematocrit and hemoglobin concentration compared to animals of GIV on D31. Iron stores in the bone marrow were higher in GII and GIII compared to GI and GIV. The GIV showed lower seric levels of iron on D24 compared to the other groups. The iron supplementation reduces the severity of the anemia caused by infection with Haemonchus contortus in lambs, improving erythropoietic response after blood loss.
\end{abstract}

INDEX TERMS: Iron supplementation, lambs, Haemonchus contortus, anemia, bone marrow, helminths, sheep, clinics.

\begin{abstract}
RESUMO.- [Suplementação com ferro em cordeiros infectados experimentalmente por Haemonchus contortus: resposta a anemia e as reservas de ferro na medula óssea.] Para avaliar o efeito da suplementação de ferro dextrano sobre variáveis sanguíneas e metabolismo do ferro em cordeiros experimentalmente infectados por Haemonchus contortus, foram utilizados quatro grupos experimentais: animais não
\end{abstract}

\footnotetext{
${ }^{1}$ Received on September 1, 2017.

Accepted for publication on September 12, 2017.

2 Departamento de Grandes Animais, Universidade Federal de Santa Maria (UFSM), Avenida Roraima 1000, Santa Maria, RS 97105-900, Brazil. *Corresponding author: martalizandra@gmail.com

${ }^{3}$ Departamento de Pequenos Animais, Universidade Federal de Santa Maria (UFSM), Av. Roraima 1000, Santa Maria, RS 97105-900.

${ }^{4}$ Departamento de Farmacologia, Universidade Federal de Santa Maria (UFSM), Av. Roraima 1000, Santa Maria, RS 97105-900.

${ }^{5}$ Departamento de Zootecnia, Universidade do Estado de Santa Catarina (UDESC), Rua Beloni Trombeta Zanin, Chapecó, SC 89815-630, Brazil.
}

infectados e não suplementados (GI); animais infectados e suplementados com ferro (GII); animais não infectados e suplementados com ferro (GIII); e animais não suplementados infectados (GIV). Os grupos II e IV receberam 10.000 larvas (L3) de Haemonchus contortus, e os grupos II e III receberam três doses de ferro dextrano $(20 \mathrm{mg} / \mathrm{kg})$ por via intramuscular com sete dias de intervalo. As amostras de sangue e fezes foram coletadas nos dias 10 (D10), 17 (D17), 24 (D24) e 31 (D31), para determinar o eritrograma, o metabolismo do ferro e a quantidade de ovos por gramas de fezes (OPG). Os cordeiros infectados desenvolveram anemia no D24, sendo esta mais severa no dia 31. Os cordeiros do GII apresentaram maior hematócrito e concentração de hemoglobina em comparação com animais dd GIV no D31. Os estoques de ferro na medula óssea foram maiores no GII e GIII em comparação com o GI e GIV. O GIV mostrou menores níveis séricos de ferro no D24 em comparação com os outros grupos. A suplementação de ferro reduz a gravidade da anemia causada por infecção por 
Haemonchus contortus em cordeiros, melhorando a resposta eritropoietica após a perda de sangue.

TERMOS DE INDEXAÇÃO: Suplementação com ferro, cordeiros, Haemonchus contortus, anemia, reserva de ferro, medula óssea, ferro, helmintos, ovinos, clínica.

\section{INTRODUCTION}

Sheep production is an important source of income through the exploration of meat, milk, and wool from the animals (Pinheiro et al. 2000). In semi-intensive and intensive farming systems, infection by gastrointestinal nematodes is the major problem, and the infections caused by parasites of the genus Haemonchus are the most common in Brazilian sheep flocks (Amarante et al. 2004). The consequence of the blood sucking habits of this parasite is an iron deficiency anemia and hypoproteinemia in the hosts (Rocha et al. 2013). Such alterations cause a sharp reduction in average daily gain (ADG) and in many cases, death of infected animals. After approximately two weeks of infection, a severe anemia develops, when the parasitic plunder exceeds the erythropoietic response capacity, and the degree of anemia varies according to sex, age, species of the parasite, and resistance of infected animals (Weiss \& Wardrop 2010).

Iron is vital for cellular homeostasis, and is a key component for the formation of heme fraction that participates in the synthesis of several proteins, which are responsible for oxygen transport, cell energy generation, and detoxification. Heme is synthesized in all nucleated cells, and the largest amount is produced by the erythroid tissue (Andrews 2005, Grotto 2008). In cases of iron deficiency anemia, such as those caused by Haemonchus contortus, there is a decrease of iron in the body, reduction of iron stores, and finally tissue deficiency (Wijayanti et al. 2004).

The relative iron total body distribution is divided in functional, storage and transport compartments. Approximately 60 to $70 \%$ of total iron is bound to haemoglobin, 20 to $30 \%$ is stored as ferritin and hemosiderin (in macrophages and hepatocytes), 3 to $7 \%$ in myoglobin, 1\% in enzymes and only $0,1 \%$ bound to plasmatic transferrin (Kaneko et al. 2008). These compartments are affected sequentially and whenever iron is lost, the stores are the first to be affected due to metal mobilization in order to meet organic requirements. Sequentially, a deficit in iron fraction during blood transport follows and, finally, a deficiency in the functional erythroid compartment (Krishnamurthy et al. 2007). Therefore, the appropriate way to evaluate body iron status is to assess its serum concentrations, ferritin, transferrin, transferrin saturation, the total iron binding capacity of transferrin and the iron stores in the bone marrow (Frazer \& Anderson 2003).

We hypothesized that supplementation with injectable iron in sheep infected by $H$. contortus could increase iron levels in the body and, therefore, improve their response to iron deficiency anemia. In this context, this study aimed to evaluate the effect of injectable iron supplementation in lambs experimentally infected by $H$. contortus.

\section{MATERIALS AND METHODS}

The experimental protocol was approved by the Committee of Ethics in Animal Use of the Federal University of Santa Maria (119/2014).
Animals. 24 male crossbred (Corriedale x Texel) lambs with approximately four months of age and average and weight of $17 \mathrm{~kg}$ were housed in collective boxes (one per group), located at the Veterinary Hospital of the Federal University of Santa Maria (UFSM). The lambs went through a period of 30 days for adaptation to the diet and environment (covered shed). During this period the animals were treated with anthelmintic monepantel (Zolvix ${ }^{\circledR}$ - Novartis Animal Health). The animals were fed three times a day using a diet composed by oat hay (Avena sativa) and concentrate (soybean meal and wheat bran) in the proportion of 60:40, respectively, totalling $13 \%$ of crude protein. This diet contained $39 \mathrm{mg}$ of iron per $/ \mathrm{kg} /$ dry matter.

Experimental design. The lambs were divided into four groups of six lambs each, as follows: the uninfected and non-supplemented group (GI); the infected group and supplemented with iron (GII); the uninfected group and supplemented with iron (GIII); and the infected and non-supplemented group (GIV). Iron was administered in three doses of $20 \mathrm{mg} / \mathrm{kg}$ of iron dextran (Ferrodex ${ }^{\circledR}$ - Tortuga Company Agrarian Animal Science), intramuscularly, with seven days of interval (days 10,17, and 24 of the experiment). This dosing interval was defined from the erythropoiesis, which is approximately seven days (Weiss \& Wardrop 2010).

Infection. The third-stage larvae (L3) of $\mathrm{H}$. contortus (pure culture, mono-specific) were obtained from the Department of Parasitology of the Biosciences Institute of the Universidade Estadual Paulista "Julio de Mesquita Filho". Larvae were used to infect a sheep (free of parasites), which was used as a larvae-donor. After collection, fecal samples were homogenized in water and filtered through a set of sieves $(250,75,43,25 \mu \mathrm{m})$. Subsequently, the eggs were separated by centrifugation (3000rpm for 5 minutes) with a saturated solution of sodium chloride (Coles et al. 1992, Bizimenyera et al. 2006). The L3 were obtained by culturing (Roberts \& O'Sullivan 1950), and used to infect the animals of the experimental groups.

The infection procedure was performed as described by Rowe et al. (2008) with modifications. For each animal, 10,000 L3 stage larvae previously diluted in $5 \mathrm{~mL}$ of distilled water were administered orally (GII and GIV), for three days with an interval of two days between infections. The first day of infection was set as day 0 (zero) of the experiment (D0).

Body weight. Body weight was verified using a scale (ICS-300 Coima/SP, Brazil) on day 10, 17, 24, and 31 post-infection (PI).

Fecal examination. Egg counts per gram of feces (EPG) was performed individually in the four experimental periods (days 10, 17,24 , and $31 \mathrm{PI}$ ), using the technique as recommended by Gordon \& Whitlock (1939).

Sampling. Blood samples were drawn by venipuncture of the jugular vein using vacuum collection tubes containing EDTA for hemogram and into tubes without anticoagulant for other iron estimation parameters. The analyses were performed on days $10,17,24$, and 31 post-infection (PI).

Red blood cell counts. Red blood cell (RBC) counts and hematocrits were performed using the macrodilution technique as recommended by Weiss \& Wardrop (2010). After dilution RBC counts were performed using a Neubauer chamber. The hematocrit (Ht) was performed on calibrated capillary tubes with homogeneous diameter using a microcentrifuge. Hemoglobin concentration $(\mathrm{Hb})$ was determined in a spectrophotometer using a commercial kit (Bioclin, Belo Horizonte, Minas Gerais). Based on erythrogram, the mean corpuscular volume values (MCV) and mean corpuscular hemoglobin concentration (MCHC) were calculated. The identification of reticulocytes stained by new methylene blue was performed 
during the count of 1000 erythrocytes in homogeneous microscopic fields and (Birgel 1982).

Iron metabolism. For the determination of iron stores in the bone marrow, a semi-quantitative assessment of iron particles in bone marrow smears using Pearl's reaction was performed (Rath \& Finch 1948). The bone marrow harvesting was performed on day 17, 24, and 31 of the experiment where each animal received an analgesic $(2.0 \mathrm{mg} / \mathrm{kg}$ of tramadol hydrochloride 4\%) intramuscularly $30 \mathrm{~min}$ prior to the procedure. Then, the animals were placed in dorsal decubitus, and after trichotomy and antisepsis with alcohol-iodine-alcohol, the middle region of the sternum was anesthetized with $1 \mathrm{~mL}$ of $2 \%$ lidocaine hydrochloride subcutaneously. The aspiration of the bone marrow was performed with a Komiyashiki needle coupled to a $20 \mathrm{~mL}$ syringe. After the fixation of the needle, approximately $200 \mu \mathrm{L}$ was aspirated and immediately transferred to glass slides for the preparation of smears. Subsequently, the smears were subjected to Pearls' reaction, using potassium ferrocyanide, hydrochloric acid, and Carmalumem Mayer (EasyPath, Erviegas Ltda, São Paulo, Brazil). The bone marrow slides were visualized under microscope with a 400x magnification and the examiner had no assess to the groups or day of sampling (blind analysis). The assessment of iron store in the bone marrow was performed based on the number of stained particles in the smears, followed by a grading method using a scale of $0,1,2,3,4,5$, to 6 representing none, very slight, mild, moderate, moderately heavy, heavy, and very heavy, respectively (Rath \& Finch 1948).

The total iron binding capacity of transferrin (TIBC) was determined by the colorimetric method of Goodwin (FerroZine). Seric levels of iron were measured using a commercial kit (Bioclin, Belo Horizonte, Minas Gerais). Ferritin was analyzed by the turbidity method using a commercial kit (Bioclin, Belo Horizonte, Minas Gerais). From the TIBC, the value of transferrin (Tf) was obtained by the formula $(\mathrm{Tf}(\mathrm{mg} / \mathrm{dl})=\mathrm{TIBC} \times \mathrm{0.7})$ and also the transferrin saturation index (STI) was obtained with the formula (STI $(\%)=$ (seric iron/TIBC) $x$ 100), according to Kaneko et al. (2008).

Statistical analysis. The data were tested for normality and homogeneity of variance by the Kolmogorov-Smirnov test. Those with normal distribution were submitted to analysis of variance, followed by the comparison Tukey's test. The nonparametric data (number of reticulocytes, the bone marrow iron scores, ferritin, and EPG) underwent logarithmic transformation $(\log x+1)$ followed by the Tukey's test (Sampaio 1998). The significance level was 5\%. For a description of the results, average and standard error were used. The analyses were performed using a statistical software (Minitab 17.0).

\section{RESULTS AND DISCUSSION}

The experiment could be carried on 23 lambs, since on day $14 \mathrm{PI}$, one animal from infected and non-supplemented group (GIV) was excluded due to the clinical signs (lethargia, weakness, hyporexia) and severity of anemia $(<15 \% \mathrm{Ht})$. This lamb was treated with anthelmintic, received blood transfusion and recovered. There was no difference on body weight of the animals during the experiment.

\section{Parasitological examinations}

No eggs per gram of faeces in groups I and III were detected during the experimental period (Table 1). On days 24 and 31 PI, EPG analysis of animals from groups II and IV showed the presence of Haemonchus contortus eggs, demonstrating that the experimental infection was successful. In this study, we
Table 1. Mean values and standard error of eggs per gram of feces of lambs infected or not by Haemonchus contortus and supplemented or not with iron dextran

\begin{tabular}{ccc}
\hline Days & Group & EPG \\
\hline D10 & G1 & $0,00 \pm 0,00^{\mathrm{a}}$ \\
& GII & $0,00 \pm 0,00^{\mathrm{a}}$ \\
& GIII & $0,00 \pm 0,00^{\mathrm{a}}$ \\
GIV & $0,00 \pm 0,00^{\mathrm{a}}$ \\
& GI & $0,00 \pm 0,00^{\mathrm{a}}$ \\
& GII & $0,00 \pm 0,00^{\mathrm{a}}$ \\
& GIII & $0,00 \pm 0,00^{\mathrm{a}}$ \\
& GIV & $0,00 \pm 0,00^{\mathrm{a}}$ \\
& GI & $0,00 \pm 0,00^{\mathrm{a}}$ \\
& GII & $6150 \pm 1564^{\mathrm{a}}$ \\
& GIII & $0,00 \pm 0,00^{\mathrm{a}}$ \\
D31 & GIV & $5980 \pm 1644^{\mathrm{a}}$ \\
& GI & $0,00 \pm 0,00^{\mathrm{a}}$ \\
& GII & $12967 \pm 3893^{\mathrm{a}}$ \\
& GIII & $0,00 \pm 0,00^{\mathrm{a}}$ \\
& GIV & $14140 \pm 2632^{\mathrm{a}}$
\end{tabular}

D10 = day 10, D17 = day 17, D24 = day 24, D21 = day 21, EPG = eggs per gram of feces. GI = group 1, animals were neither infected nor supplemented with iron; GII = group 2, animals were infected with larvae and supplemented with iron; GIII = group 3, uninfected animals supplemented with iron; GIV = group 4, animals infected with larvae of the parasite but not treated. Unmatched letters in the columns denote statistical difference between values and should be analyzed from the comparison with the same moments between different groups.

chose to sample at day 17,24 and 31 , and the detection of eggs on day 24 and 31 is coherent to literature data, because of the prepatent period in $H$. contortus infections, which is approximately of 19 to 21 days (Zajac 2006). The EPG values (Table 1) were similar in GII and GIV animals ( $p>0.005$ ). These results were expected, since there is no reported influence of iron on $H$. contortus infection ability. However, according to Levecke et al. (2011), EPG is of low sensitivity in determining the infection rate, because a very high parasitic load could reduce egg excretion by the parasites. Clinically and laboratory this difference was seen by the better health status and hematologic values observed in the lambs from GII, in comparison to the ones in GIV.

\section{Hemogram}

Table 2 presents the hematologic values obtained in the experiment. From day 24 PI, significant differences could be seen among the infected and non-infected lambs. Infected animals (GII and GIV) were anaemic, and had lower $\mathrm{RBC}$ count, $\mathrm{Ht}$ and $\mathrm{Hb}$ concentration compared to uninfected animals (GI and GIII) ( $\mathrm{p}<0.0001)$. On day 31, GII and GIV had a worsening in anemia and GIV had lower $\mathrm{CHCH}$ in comparison to GI, GII and also to GII. In this group, the reticulocyte count was higher in comparison to all groups. This can be explained by the severity of anemia caused by $H$. contortus infection in these animals (González \& Silva 2003) on day 31 (Ht 17+0,37, $\mathrm{Hb} 5,47+0,24)$, and the correspondent bone marrow response to hypoxia (Weiss \& Wardrop 2010, Birgel et al. 2014). 
In order to assess bone marrow iron stores in supplemented and non-supplemented groups, Prussian Blue staining was used, according to Rath \& Finch (1948). The medullary iron scores were graded from 0-6 and were higher in the animals which received iron intramuscularly (GII and GIII) on days 17, 24, and 31 PI than those not supplemented (GI and GIV) (Table 3) $(\mathrm{p}<0.0001)$. According to Grotto (2010), Prussian Blue staining of bone marrow aspirates is the gold standard test for measuring iron stores in relation to the determination of seric iron, the TIBC and STI, since these markers may also

Table 2. Mean values and standard error of the erythrogram of lambs infected or not by Haemonchus contortus and supplemented or not with iron dextran

\begin{tabular}{|c|c|c|c|c|c|c|c|}
\hline \multirow{2}{*}{ Day } & \multirow{2}{*}{ Group } & $\mathrm{RBC}$ & $\mathrm{Ht}$ & $\mathrm{HgB}$ & MCV & $\mathrm{MCHC}$ & Reticulocytes \\
\hline & & $\mathrm{n}^{\circ} \times 106 / \mu \mathrm{l}$ & $\%$ & $\mathrm{~g} / \mathrm{dL}$ & $\mathrm{fL}$ & $\%$ & $\%$ \\
\hline \multirow[t]{4}{*}{ D10 } & GI & $10,65 \pm 0,92^{\mathrm{a}}$ & $32,17 \pm 1,14^{\mathrm{a}}$ & $12,53 \pm 0,53^{\mathrm{a}}$ & $31,02 \pm 2,31^{\mathrm{a}}$ & $38,95 \pm 1,17^{\mathrm{a}}$ & $0,08 \pm 0,03^{\mathrm{a}}$ \\
\hline & GII & $11,02 \pm 0,70^{\mathrm{a}}$ & $30,83 \pm 1,35^{\mathrm{a}}$ & $12,23 \pm 0,91^{\mathrm{a}}$ & $28,08 \pm 0,82^{\mathrm{a}}$ & $39,38 \pm 1,42^{\mathrm{a}}$ & $0,08 \pm 0,04^{\mathrm{a}}$ \\
\hline & GIII & $9,88 \pm 0,23^{\mathrm{a}}$ & $30,33 \pm 1,65^{\mathrm{a}}$ & $11,80 \pm 0,78^{a}$ & $30,63 \pm 1,53^{\mathrm{a}}$ & $38,88 \pm 1,55^{a}$ & $0,26 \pm 0,11^{\mathrm{a}}$ \\
\hline & GIV & $11,66 \pm 0,54^{\mathrm{a}}$ & $32,40 \pm 1,33^{a}$ & $12,94 \pm 0,60^{\mathrm{a}}$ & $27,84 \pm 1,09^{\mathrm{a}}$ & $39,94 \pm 1,34^{a}$ & $0,10 \pm 0,05^{\mathrm{a}}$ \\
\hline \multirow[t]{2}{*}{ D17 } & GI & $10,38 \pm 0,54^{\mathrm{a}}$ & $30,67 \pm 1,05^{\mathrm{a}}$ & $11,44 \pm 0,54^{\mathrm{a}}$ & $31,00 \pm 0,74^{a}$ & $37,25 \pm 1,00^{a}$ & $0,05 \pm 0,05^{\mathrm{a}}$ \\
\hline & GIV & $8,88 \pm 0,39^{a}$ & $26,20 \pm 1,59^{a}$ & $9,58 \pm 0,57^{a}$ & $30,72 \pm 1,51^{\mathrm{a}}$ & $36,54 \pm 0,19^{a}$ & $0,24 \pm 0,09^{\mathrm{a}}$ \\
\hline \multirow[t]{4}{*}{ D24 } & GI & $10,18 \pm 0,59^{a}$ & $31,33 \pm 1,12^{\mathrm{a}}$ & $11,10 \pm 0,50^{\mathrm{a}}$ & $31,00 \pm 1,26^{a}$ & $35,08 \pm 0,88^{a}$ & $0,98 \pm 0,17^{\mathrm{a}}$ \\
\hline & GII & $6,53 \pm 0,48^{b}$ & $22,50 \pm 1,45^{b}$ & $7,63 \pm 0,48^{b}$ & $34,67 \pm 1,33^{\mathrm{a}}$ & $33,96 \pm 0,80^{a}$ & $2,05 \pm 0,29^{\mathrm{a}}$ \\
\hline & GIII & $9,92 \pm 0,30^{\mathrm{a}}$ & $29,50 \pm 0,84^{\mathrm{a}}$ & $10,92 \pm 0,39^{a}$ & $29,85 \pm 1,48^{\mathrm{a}}$ & $35,32 \pm 1,25^{\mathrm{a}}$ & $1,35 \pm 0,25^{\mathrm{a}}$ \\
\hline & GIV & $5,89 \pm 0,59^{b}$ & $20,00 \pm 1,38^{b}$ & $6,76 \pm 0,51^{b}$ & $34,50 \pm 1,99^{a}$ & $33,80 \pm 1,13^{\mathrm{a}}$ & $1,82 \pm 0,51^{\mathrm{a}}$ \\
\hline D31 & GIV & $5,00 \pm 0,32^{\mathrm{b}}$ & $17,20 \pm 0,37^{c}$ & $5,47 \pm 0,24^{c}$ & $34,74 \pm 1,67^{a}$ & $31,70 \pm 0,86^{\mathrm{b}}$ & $3,04 \pm 0,52^{\mathrm{a}}$ \\
\hline
\end{tabular}

D10 = day 10, D17 = day 17, D24 = day 24, D31 = day 31, RBC = red blood cell, Ht = hematocrit, Hb = hemoglobin, MCV = mean corpuscular volume $\mathrm{MCHC}=$ mean circulating hemoglobin concentration; GI = group 1, animals neither infected nor supplemented with iron; GII = group 2, animals infected with larvae and supplemented with iron; GIII = group 3, uninfected animals supplemented with iron; GIV = group 4, animals infected with larvae of the parasite but non supplemented. Different letters in the same column denote statistical difference between values and it should be analyzed by comparing the same period between different groups.

Table 3. Mean values and standard error of iron metabolism from lambs infected or not by Haemonchus contortus and treated or not with iron dextran

\begin{tabular}{|c|c|c|c|c|c|c|c|}
\hline \multirow{2}{*}{ Day } & \multirow{2}{*}{ Group } & Iron & $\mathrm{Tf}$ & $\mathrm{Ft}$ & SIT & TIBC & Medullary iron \\
\hline & & $\mu \mathrm{g} / \mathrm{dL}$ & $\mathrm{mg} / \mathrm{dL}$ & $\mu \mathrm{g} / \mathrm{L}$ & $\%$ & $\mu \mathrm{g} / \mathrm{dL}$ & scores \\
\hline \multirow[t]{4}{*}{ D10 } & GI & $96,5 \pm 11,7^{\mathrm{a}}$ & $188,2 \pm 26,8^{\mathrm{a}}$ & $4,08 \pm 3,35^{a}$ & $39,8 \pm 6,62^{\mathrm{a}}$ & $286,8 \pm 38,2^{\mathrm{a}}$ & - \\
\hline & GII & $117,5 \pm 26,7^{\mathrm{a}}$ & $148,9 \pm 17,7^{\mathrm{a}}$ & $1,93 \pm 1,53^{\mathrm{a}}$ & $54,13 \pm 8,80^{\mathrm{a}}$ & $212,7 \pm 25,3^{\mathrm{a}}$ & - \\
\hline & GIII & $139,8 \pm 23,0^{\mathrm{a}}$ & $121,7 \pm 19,9^{a}$ & $2,37 \pm 1,89^{a}$ & $90,1 \pm 21,7^{a}$ & $173,8 \pm 28,4^{\mathrm{a}}$ & - \\
\hline & GIV & $120,8 \pm 8,73^{\mathrm{a}}$ & $157,5 \pm 15,8^{\mathrm{a}}$ & $0,70 \pm 0,23^{\mathrm{a}}$ & $55,82 \pm 7,21^{\mathrm{a}}$ & $225,0 \pm 22,6^{a}$ & - \\
\hline \multirow[t]{4}{*}{ D17 } & GI & $96,3 \pm 13,3^{b}$ & $155,7 \pm 20,3^{a}$ & $0,69 \pm 0,25^{\mathrm{a}}$ & $48,57 \pm 9,90^{\mathrm{a}}$ & $222,5 \pm 29,0^{\mathrm{a}}$ & $0,00 \pm 0,00^{c}$ \\
\hline & GII & $153,0 \pm 17,7^{b}$ & $129 \pm 10^{\mathrm{ab}}$ & $1,29 \pm 0,89^{a}$ & $87,0 \pm 14,5^{\mathrm{a}}$ & $184,3 \pm 14,3^{\mathrm{ab}}$ & $4,50 \pm 0,22^{b}$ \\
\hline & GIII & $243,5 \pm 31,1^{\mathrm{a}}$ & $74 \pm 10,4^{\mathrm{b}}$ & $1,78 \pm 1,21^{\mathrm{a}}$ & $274,1 \pm 73,9^{a}$ & $105,7 \pm 14,8^{\mathrm{b}}$ & $5,00 \pm 0,00^{\mathrm{a}}$ \\
\hline & GIV & $160,2 \pm 12^{\mathrm{ab}}$ & $112,4 \pm 23,8^{\mathrm{ab}}$ & $0,49 \pm 0,09^{a}$ & $179,9 \pm 99,5^{\mathrm{a}}$ & $160,6 \pm 34,1^{\mathrm{ab}}$ & $0,00 \pm 0,00^{c}$ \\
\hline \multirow[t]{4}{*}{ D24 } & GI & $136,5 \pm 18,1^{\mathrm{a}}$ & $161,3 \pm 20,4^{\mathrm{ab}}$ & $0,47 \pm 0,04^{\mathrm{a}}$ & $60,03 \pm 19,6^{b}$ & $234,5 \pm 26,9^{\mathrm{a}}$ & $0,50 \pm 0,22^{\mathrm{b}}$ \\
\hline & GII & $169,2 \pm 20,1^{\mathrm{a}}$ & $99,8 \pm 20,4^{\mathrm{bc}}$ & $1,53 \pm 0,94^{\mathrm{a}}$ & $133,1 \pm 18,1^{\mathrm{b}}$ & $142,5 \pm 29,2^{\mathrm{b}}$ & $4,66 \pm 0,21^{a}$ \\
\hline & GIII & $181,8 \pm 24,9^{\mathrm{a}}$ & $35,9 \pm 8,5^{c}$ & $1,79 \pm 1,13^{\mathrm{a}}$ & $459,2 \pm 40,8^{\mathrm{a}}$ & $51,3 \pm 12,3^{c}$ & $5,00 \pm 0,00^{\mathrm{a}}$ \\
\hline & GIV & $48,6 \pm 8,70^{\mathrm{b}}$ & $183,8 \pm 12,1^{\mathrm{a}}$ & $3,04 \pm 2,64^{a}$ & $18,36 \pm 2,87^{b}$ & $262,6 \pm 17,3^{a}$ & $0,00 \pm 0,00^{c}$ \\
\hline \multirow[t]{4}{*}{ D31 } & GI & $178,7 \pm 32,6^{\mathrm{a}}$ & $120,1 \pm 27,4^{\mathrm{a}}$ & $1,22 \pm 0,67^{\mathrm{a}}$ & $147,7 \pm 57,7^{\mathrm{a}}$ & $171,5 \pm 39,2^{\mathrm{a}}$ & $0,33 \pm 0,21^{b}$ \\
\hline & GII & $129,8 \pm 40,9^{\mathrm{a}}$ & $144,5 \pm 23,4^{\mathrm{a}}$ & $0,40 \pm 0,00^{\mathrm{a}}$ & $71,9 \pm 21,0^{a}$ & $206,5 \pm 33,4^{a}$ & $5,00 \pm 0,00^{a}$ \\
\hline & GIII & $103,4 \pm 23,2^{\mathrm{a}}$ & $161,4 \pm 44,8^{\mathrm{a}}$ & $0,40 \pm 0,00^{\mathrm{a}}$ & $66,1 \pm 22,0^{\mathrm{a}}$ & $230,6 \pm 64,0^{\mathrm{a}}$ & $5,66 \pm 0,21^{a}$ \\
\hline & GIV & $142,2 \pm 20,2^{\mathrm{a}}$ & $65,4 \pm 12,4^{\mathrm{a}}$ & $0,40 \pm 0,00^{\mathrm{a}}$ & $185,6 \pm 57,3^{\mathrm{a}}$ & $93,4 \pm 17,7^{\mathrm{a}}$ & $0,00 \pm 0,00^{c}$ \\
\hline
\end{tabular}

$\mathrm{D} 10=$ day $10, \mathrm{D} 17=$ day $17, \mathrm{D} 24=$ day $24, \mathrm{D} 31=$ day $31, \mathrm{Ft}=$ ferritin, $\mathrm{Tf}=$ transferrin, STI = transferrin saturation index, TIBC $=$ total binding capacity of iron to transferrin; GI = group 1, animals neither infected, nor treated with iron; GII = group 2, animals infected with larvae and treated with iron; GIII = group 3, uninfected animals treated with iron; GIV = group 4, animals infected with larvae of the parasite but untreated. Unmatched letters in the columns denote statistical difference between values and should be analyzed from the comparison with the same moments between different groups. 
change depending on the inflammation response (Krause \& Stolc 1979, Kaneko et al. 2008). Infected animals and treated with iron dextrose showed higher scores of medullary iron compared to the infected group (GIV), demonstrating that the treatment with iron helps in the maintenance stored levels of this mineral. Interestingly, non-infected animals (GI) and infected non-supplemented animals (GII) had similar low iron scores (except on D17). In healthy cats and some cattle there can be a lack of stainable iron in the bone marrow (Weiss \& Wardrop 2010). We could not find any reference about iron staining in sheep bone marrow, but since in the control group the iron scores were low, probably there is little iron stored in normal sheep bone marrow (scores 0.00 to 05 ). In supplemented animals (GII and GIII), iron bone marrow was markedly higher in comparison to the other groups. This confirms the bone marrow serves as a place for iron storage in sheep (Weiss \& Wardrop 2010).

\section{Iron metabolism}

On day $17 \mathrm{PI}$, the seric levels of iron were higher in GIII compared to GI and GII, GIV levels were between those groups (Table 3; $\mathrm{p}$ 0.0006). Together with the iron bone marrow analysis, this result shows that animals belonging to this group had lower iron requirements, since they had been supplemented and were not challenged. TIBC and seric transferrin levels were higher in the GI in comparison to GIII ( $<<0.0157$ and $p<0.0015$, respectively) (Table 3). These results confirm the previous statement, because less iron was bound to transport proteins increasing the TIBC and transferrin levels in the GI.

On day $24 \mathrm{PI}$, animals from GIV showed lower levels of seric iron compared to groups I, II, and III ( $p<0.0008)$. These animals had lower RBC count, haematocrit, haemoglobin on this day showing that not only free iron was decreased, but also functional iron. Animals from groups I and IV showed higher iron binding capacity compared to those from groups II and III $(p<0.0001)$, and the average values of transferrin were higher in the infected and untreated group (GIV) compared to the groups that received iron (GII and GIII) $(p<0.0001)$. The STI was higher in GIII compared to the other groups $(\mathrm{p}<0.0001)$ (Table 3), showing that supplemented animals had significantly higher amounts of available iron. There was no difference in ferritin levels during the experimental period ( $p>0.05$ ). According to Gonzáles (2000), the peak of iron absorption $(60 \%)$ occurs within 72 hours after application of the product. Three doses of $20 \mathrm{mg} / \mathrm{kg}$ BW of iron dextran used intramuscularly (at times 10,17, and $24 \mathrm{PI}$ ), released higher amounts of the metal.

Although higher concentrations of ferritin are present in the liver and spleen, only a small amount is circulating in the serum, which is totally free of iron. The quantification of ferritin determines the iron content in the stock compartment (Grotto 2010). During the study period, there were no differences in seric ferritin levels. However, smaller numerical values of this protein were detected in lambs from the infected and untreated group in relation to other groups on days 10,17, and $31 \mathrm{PI}$, suggesting iron deficiency in animals of this group.

Taken together, lambs infected with $H$. contortus and supplemented with iron intramuscularly had higher RBC counts, $\mathrm{Ht}, \mathrm{Hb}$ concentration and available iron than infected control animals showing a possible role of iron supplementation in stress erythropoiesis.

\section{CONCLUSION}

The results indicate that injectable iron reduces the severity of anemia in lambs infected with Haemonchus contortus, maintaining iron stores in the bone marrow, thus supporting erythopoiesis.

Acknowledgements.- We would like to thank Fundação de Amparo à Pesquisa do Rio Grande do Sul (FAPERGS) for a scholarship and also Professor Alessandro F.T. do Amarante and the Universidade Estadual Paulista (Unesp) for providing infective larvae of Haemonchus contortus.

\section{REFERENCES}

Amarante A.F.T., Bricarello P.A., Rocha R.A. \& Gennari S.M. 2004. Resistance of Santa Ines, Suffolk and Ile de France sheep to naturally acquired gastrointestinal nematode infections. Vet. Parasitol. 120(1/2):91-106. <http://dx.doi.org/10.1016/j.vetpar.2003.12.004> <PMid:15019147>

Andrews N.C. 2005. Molecular control of iron metabolism. Best Pract. Res. Clin. Haematol.18(2):159-169. <http://dx.doi.org/10.1016/j.beha.2004.10.004> $<$ PMid:15737882>

Birgel D.B., Muller A.F., Fantinato-Neto P., Storillo V.M., Benesi F.J. \& Birgel Junior E.H. 2014. Avaliação do quadro eritrocitário e da repercussão do estado anêmico no leucograma de caprinos com verminose gastrintestinal. Pesq. Vet. Bras. 34(3):199-204. <http://dx.doi.org/10.1590/S0100736X2014000300001>

Birgel E.H. 1982. Hematologia clínica veterinária, p.2-34. In: Birgel E.H. \& Benesi F.J. (Eds), Patologia Clínica Veterinária. Sociedade Paulista de Medicina Veterinária, São Paulo, SP.

Bizimenyera E.S., Githiori J.B., Eloff J.N. \& Swan G.E. 2006. In vitro activity of Peltophorum africanum Sond. (Fabacea) extracts on the egg hatching and larval development of the parasitic nematode Trichostrongylus colubriformis. Vet. Parasitol. 142(3/4):336-343.<http://dx.doi.org/10.1016/j. vetpar.2006.06.013><PMid:16899339>

Coles G.C., Bauer C., Borgsteede F.H., Geerts S., Klei T.R., Taylor M.A. \& Waller P.J. 1992. World Association for the Advancement of Veterinary Parasitology (WAAVP) methods for the detection of anthelmintic resistance in nematodes of veterinary importance. Vet. Parasitol. 44(1/2):35-44. <http://dx.doi. org/10.1016/0304-4017(92)90141-U><PMid:1441190>

Frazer D.M. \& Anderson G.J. 2003. The orchestration of body iron intake: how and where do enterocytes receive their cues? Blood Cells Molecules Dis. 30(3):288-297. <http://dx.doi.org/10.1016/S1079-9796(03)000391><PMid:12737947>

Gonzáles A.R. 2000. Anemias: tratamento farmacológico. Boln Farmacoter. Castilla La Mancha 82:1-8.

González F.D. \& Silva S. 2003. Introdução à Bioquímica Clínica Veterinária. UFRGS, Porto Alegre. 535p.

Gordon H.McL. \& Whitlock A.V. 1939. A new technique for counting nematode eggs in sheep feces. J. Couns. Scient. Industr. Res. 12:50-52.

Grotto H.Z.W. 2008. Metabolismo do ferro: uma revisão sobre os principais mecanismos envolvidos em sua homeostase. Revta Bras. Hematol. Hemoter. 30(5):390-397. <http://dx.doi.org/10.1590/S1516-84842008000500012>

Grotto H.Z.W. 2010. Fisiologia e metabolismo do ferro. Revta Bras. Hematol. Hemoter. 32:8-17.<http://dx.doi.org/10.1590/S1516-84842010005000050>

Kaneko J.J., Harvey J.W. \& Bruss M.L. 2008. Clinical Biochemistry of Domestic Animals. Vol.6. Academic Press, Elsevier, p.178-184. 
Krause J.R. \& Stolc V. 1979. Serum ferritin and bone marrow iron stores I. Correlation with absence if iron biopsy specimens. Am. J. Clin. Pathol. 72(5):817-820. <http://dx.doi.org/10.1093/ajcp/72.5.817><PMid:506995>

Krishnamurthy P., Xie T. \& Schuetz J.D. 2007. The role of transporters in cellular heme and porphyrin homeostasis. Pharmacol. Therapeutics 114(3):345-358.<http://dx.doi.org/10.1016/j.pharmthera.2007.02.001> $<$ PMid:17368550>

Levecke B., Rinaldi L., Charlier J., Maurelli M.P., Morgoglione M.E., Vercruysse J. \& Cringoli G. 2011. Monitoring drug efficacy against gastrointestinal nematodes when faecal egg counts are low: do the analytic sensitivity and the formula matter? Parasitol. Res. 109(3):953-957. <http://dx.doi org/10.1007/s00436-011-2338-Z> <PMid:21472403>

Pinheiro R.R., Gouveia A.M.G., Alves F.S.F. \& Haddad J.P.A. 2000. Aspectos epidemiológicos na caprinocultura cearense. Arq. Bras. Med. Vet. Zootec. 52(5):534-543. <http://dx.doi.org/10.1590/S0102-09352000000500021>

Rath C.E. \& Finch C.A. 1948. Sternal marrow haemosiderin: a method for the determination of available iron stores in man. J. Lab. Clin. Med. 6:33-81. <PMid:18907892>

Roberts F.H.S. \& O’Sullivan P.J. 1950. Methods for egg counts and larval cultures for strongyles infesting the gastrointestinal tract of cattle. Aust J. Agricult. Res. 1(1):99-102. <http://dx.doi.org/10.1071/AR9500099>
Rocha R.X., Filappi A., Rodrigues A., Soares E., Fernandes G., Leal M.L.R. \& Cecim M. 2013. Desempenho ponderal, função hepática e hemograma de borregos naturalmente infectados por helmintos gastrointestinais suplementados com ferro oral ou parenteral. Revta Bras. Ciênc. Vet. 20:189-193.

Rowe A., Gondro C., Emery D. \& Sangster N. 2008. Genomic analyses of Haemonchus contortus infection in sheep: Abomasal fistulation and two Haemonchus strains do not substantially confound host gene expression in microarrays. Vet. Parasitol. 154(1/2):71-81. <http://dx.doi.org/10.1016/j. vetpar.2008.02.014><PMid:18387746>

Sampaio I.B.M. 1998. Estatística aplicada à experimentação animal. Vol.1. Fundação de Ensino e Pesquisa de Medicina Veterinária e Zootecnia, p.1-221.

Weiss D.J. \& Wardrop J.K. 2010. Schalm's Veterinary Hematology. 6th ed. Wiley-Blackwell, Oxford. 1232p.

Wijayanti N., Katz N. \& Immenschuh S. 2004. Biology of heme in health and disease. Med. Chemistry 11(8):981-986. <PMid:15078160>

Zajac A.M. 2006. Gastrointestinal nematodes of small ruminants: life cycle, anthelmintics, and diagnosis. Vet. Clin. N. Am., Food Anim. Pract. 22(3):529541. <http://dx.doi.org/10.1016/j.cvfa.2006.07.006> 